\title{
The Regional Dimension of Statebuilding Interventions
}

By Benjamin Brast (2015)

PhD Fellow at Bremen International Graduate School of Social Sciences

This paper is an accepted manuscript (AM). The article has been published in:

International Peacekeeping, 22(1), p.81-99

http://dx.doi.org/10.1080/13533312.2014.995904

\begin{abstract}
In the post-Cold War era, liberal statebuilding interventions have become a major tool of global governance. Yet, the variation in outcomes is still poorly understood. This article draws on state formation theory to elaborate a causal mechanism that can explain the successful monopolization of the means of violence in statebuilding interventions. Insights from the state formation literature suggest that the regional political system is crucial for state formation and statebuilding. In order to test the hypothesis, a novel process-tracing method is applied to the case of Sierra Leone. The case study suggests that only a cooperative regional setting enables interventions to succeed.
\end{abstract}

Key Words: Monopoly on Violence, Regional Politics, Statebuilding, State Formation, Sierra Leone 
Statebuilding interventions have become one of the most studied issues of international politics, yet there is still little consensus on the causes of statebuilding success or failure. The literature has either focused on the strategies of intervening actors, or on the properties of the 'target country' to explain the outcomes of intervention. In recent years, attention has additionally shifted from the national to the local level, where some authors see the major impediments to successful statebuilding. This article argues that the study of statebuilding suffers from a level of analysis problem. Instead of focusing only on external actors, or on the national and local level, statebuilding research should re-shift attention to the regional level.

My main argument is that statebuilding interventions will succeed in establishing a monopoly on large-scale violence if they enjoy the support of key regional actors. This argument is based on an institutionalist perspective on state formation: Statehood is a regional institution, as states have historically formed in regional state systems. They are defined by their monopoly on violence and clear territorial boundaries, and the effectiveness of borders depends on the acceptance of sovereignty within the regional system. Where the rule of sovereignty is not accepted by key actors, armed groups that challenge statebuilding might receive support from neighboring states. If such support occurs, statebuilding interventions are too short-lived to monopolize the means of coercion in the hand of the government.

This article will focus only on one specific kind of statebuilding outcome in order to sharpen the analytical perspective. The monopoly on violence is a widely acknowledged core feature of statehood and, thus, by definition a necessary condition for successful liberal statebuilding. While liberal statebuilding tries to export an OECD model of statehood, it often even fails to achieve a monopoly on violence. This article first discusses the existing literature on statebuilding and the monopolization on violence, arguing that it has so far failed to provide a causal mechanism that explains when statebuilding interventions succeed in monopolizing the means of coercion. In a second step, I propose a causal mechanism which is based on the insights of state formation literature. Finally, I test the proposed mechanism by analyzing the case of the statebuilding intervention in Sierra Leone. Sierra Leone is selected as a crucial case, because the intervention was successful despite the presence of many unfavorable conditions. At the domestic level, the country had a history of weak statehood, was poor, and torn by a decade of civil war. ${ }^{1}$ At the international level, intervention was only gradually escalated, the intervention force was highly heterogeneous and mostly ill-equipped, and strategies like SSR were just emerging. ${ }^{2}$ Yet, the outcome of the statebuilding intervention was a monopoly on large-scale violence.

In order to test the proposed explanation, I apply the method of process-tracing. ${ }^{3}$ Statebuilding research has so far concerned itself rarely with methodological issues, especially with establishing causality. ${ }^{4}$ However, recent advances in qualitative research offer improved tools for causal inference in single- and small-n research designs. ${ }^{5}$ Process-tracing in particular is a useful approach to overcome the problem of indeterminacy that has traditionally been identified as a problem of case studies. ${ }^{6}$ Instead of just asking whether a cause and an outcome were present, process-tracing enables the researcher to '[..] get inside the box of causation, ${ }^{7}$ by theorizing and testing a causal mechanism. Such mechanisms contain theoretical expectations about how the cause translated into the observed outcome. 
Thus, by tracing the causal chain in a given case, the researcher can make stronger claims about causality in a single case.

The article will make three main contributions to research on international interventions and statebuilding: First, it shifts the level of analysis from either international (external actors) or domestic (national or 'the local') to the regional level. Second, it unpacks the state that is meant to be built through intervention by narrowing down the outcome of interest to one central element of statehood, namely the monopoly on violence. And, third, it applies a novel process-tracing method that allows for formulating and testing causal mechanisms in a single case study. The results suggest that conventional statebuilding interventions can succeed if specific scope conditions are in place.

\section{Intervention and the Monopoly on Violence}

While some authors have argued that globalization has undermined the importance of the centralization of coercion in the hands of state governments, ${ }^{8}$ the monopoly on the use of force is generally accepted as one of the central elements of modern statehood. ${ }^{9}$ Statebuilding interventions usually aim at the creation of a liberal state that is defined by a monopoly on violence, democracy, the rule of law, and a market-based economy. ${ }^{10}$ Consequently, there is broad consensus among scholars of different schools of thought that monopolizing the means of coercion is a necessary element of statebuilding ${ }^{11}$ although it is not sufficient for the establishment of a liberal state. However, even this minimal requirement has not been achieved in many statebuilding interventions. Before explaining the monopolization process itself, it is first necessary to explore the concept of monopoly on violence which has so far been taken for granted in the peace- and statebuilding literature.

One main problem with an under-specified concept of 'monopoly on the use of force' is that it is unclear what kind of means of violence is being monopolized. Does a government achieve a monopoly on violence when there are no armed groups in its territory, or only once all private persons are disarmed? Max Weber's ${ }^{12}$ definition of the state, as the 'organization which successfully claims the monopoly on the legitimate physical violence as means of political rule within a territory, ${ }^{13}$ has shaped the global expectation of what a state should look like. ${ }^{14}$ However, it is a problematic template for empirical analysis. Weber's definition was an ideal type that cannot be achieved empirically. Thus, this study will adopt a less demanding concept which builds on the work of Charles Tilly. ${ }^{15} \mathrm{He}$ divided the monopolization of violence into two distinct categories: War-making and state-making. While 'state making' is a multifaceted process that includes the creation of bureaucracies, local administrations, police forces, and taxation capacity, 'war making' is concerned with the control over the means of collective violence. ${ }^{16}$ Giustozzi ${ }^{17}$ has termed the 'war making'ability (arguably more concisely) as the state's monopoly on large-scale violence. Such a definition drops legitimacy because the monopoly is established by the actor that is best at accumulating coercive capabilities. ${ }^{18}$ While a monopoly on large-scale violence can lend a very basic legitimacy to the state when it provides order and security, ${ }^{19}$ legitimacy should 
rather be viewed as a property that can stabilize a monopoly once it has been established by transforming relations of power into authority. ${ }^{20}$

A state enjoys a monopoly on large-scale violence when the government is the only actor that controls the means of warfare within the state territory. Put differently, the state can prevent non-state actors from engaging in large-scale violence. The major reason for focusing on the monopoly on large-scale violence is that it is the necessary condition for all further goals of liberal statebuilding. Both democratic and authoritarian states can acquire the monopoly, but without centralized control over the means to wage war a society cannot be governed according to principles of democracy or the rule of law. ${ }^{21}$

During the last decade, statebuilding research has been dominated by a 'great debate' between proponents ('problem-solving' scholars) and critics (critical scholars, political sociologists) of statebuilding interventions. ${ }^{22} \mathrm{~A}$ closer look at the arguments of both sides reveals that each side has focused on different levels of analysis. The problem-solving scholars have tended to focus on the international level, while the critical scholars tended to analyze the domestic and local level.

Proponents of statebuilding interventions have aimed at improving the strategies of international actors. These scholars have adopted a 'lessons learned' approach. Their basic assumption is that, with the right set of strategies and a proper amount of resources, statebuilding can succeed. ${ }^{23}$ According to these authors, it is necessary to plan and execute official programs to disarm non-state actors (Disarmament, Demobilization and Reintegration; DDR), and which offer ex-rebels incentives to stay peaceful. ${ }^{24}$ Where armed groups resist disarmament, counterinsurgency (COIN) strategies have to be applied. ${ }^{25}$ At the same time, the state needs to be endowed with a strong army, accountable police forces, and courts that operate according to the rule of law (Security Sector Reform; SSR). ${ }^{26}$ International troops need to secure the country and police the population until the new state has sufficient capacities to 'own' these tasks. Thus, many authors argue that it is important to implement DDR and SSR programs at the very beginning of the intervention in order to avoid a 'security vacuum'. ${ }^{27}$ After the exit of the main intervention force, follow-up missions might be necessary to safeguard the success. ${ }^{28}$ Overall, problem-solving scholarship and policy-making have reinforced each other in generating a discourse that centers on the right strategies to build and strengthen states after civil wars or regime changes. ${ }^{29}$

Critical scholars have attacked these approaches for their alleged technocratic character. In particular, statebuilding approaches have been criticized for their indifference towards politics and social structures. ${ }^{30}$ In countries in which the government collapsed due to long-term civil war, or where there has never been a strong central state, it is usually local institutions that provide governance, including the regulation of violence. These actors range from traditional village communities to larger warlord polities. ${ }^{31}$ With respect to the monopoly on violence, Jackson ${ }^{32}$ argues that proponents have overlooked the deeply political character of SSR which amounts to nothing short of social engineering. By focusing on the technicalities of how to build armies or train police officers, researchers and practitioners 
have often overlooked the political implications these policies have in 'weak states'. 'At the heart of SSR are the core values of democracy, good governance, gender equality, transparency and accountability, as well as a desire to propagate universal human rights'.33 However, some critics of statebuilding have already shifted attention to the international level by pointing out the potentially destabilizing effects of regional war economies ${ }^{34}$ as well as '[..] the role of global capitalism and structural adjustment policies as drivers of conflict'. ${ }^{35}$

Political sociologists have additionally stressed the interaction effects between intervener and domestic actors. Giustozzi ${ }^{36}$ argues that military interventions often times undermine a government's efforts at monopolizing coercive means. Due to the presence of foreign troops, governments feel less pressured to build capable security forces. Furthermore, these interventions tend to 'freeze' monopolization processes by creating superficial security arrangements, so that social conflicts will continue after external actors have withdrawn. ${ }^{37}$ Complementarily, Barnett and Zürcher ${ }^{38}$ argue that the external actors want to exit the statebuilding mission as quickly as possible. Thus, they have an incentive to bypass central governments and to arm local actors (such as militias) in order to create short-term stability at the cost of undermining the central government's claim to a monopoly on violence.

In recent years, the critical and sociological scholars have arguably become the dominant group in statebuilding studies. This should probably be of little surprise given the failure of statebuilding missions in Afghanistan, DR Congo, Iraq or South Sudan to create at least a modicum of stability. The first great debate of statebuilding research has generated many important insights about the strategies and effects of statebuilding interventions. Nevertheless, it has not led to satisfactory explanations for the huge variation in the outcomes of interventions. ${ }^{39}$ Statebuilding has led to monopolies on large-scale violence in countries such as East Timor or Sierra Leone that are characterized by strong local institutions, poverty, a history of weak statehood and ethnic heterogeneity. Purely domestic explanations cannot account for these outcomes. At the same time, strategies such as COIN, DDR and SSR have been further developed since the success in Sierra Leone. Also, the need for a coherent approach and substantial troop contributions has been acknowledged by practitioners. Yet, interventions in Afghanistan, DR Congo or Iraq, where the external actors have applied many of the 'lessons learned' from earlier interventions, have not led to state monopolies on violence. As the next section argues, the key condition for the monopolization on violence in current statebuilding interventions is located neither at the international nor domestic level, but at the regional level.

\section{State Formation, Monopoly on Violence and Regional Politics}

State formation theory has made a comeback in recent years, first in International Relations in general, ${ }^{40}$ and, recently, in the study of statebuilding interventions. ${ }^{41}$ Most studies have focused on the belligerent dimension of state formation, arguing that current state weakness in developing countries can be explained by a lack of inter-state war. However, state formation also has a cooperative dimension which few authors of development and statebuilding have 
taken into account. ${ }^{42}$ This section argues that the systemic and cooperative elements of state formation theory are crucial to understand the emergence of a monopoly on large-scale violence. Instead of reducing state formation to a realist account of an elimination contest between political units, an institutionalist reading of the literature makes clear that the acceptance of territorial sovereignty by key actors was as important as the accumulation of the means of warfare.

The defining feature of the modern state that emerged in Europe since the $17^{\text {th }}$ century is its monopoly on making and enforcing collectively binding rules. ${ }^{43}$ Moreover, the state emerged as part of a regional system, and '[...] the distinctive feature of the modern system of rule is that it has differentiated its subject collectivity into territorially defined, fixed, and mutually exclusive enclaves of legitimate dominion'. ${ }^{44}$ Unlike empires, city-states or cityleagues, states are sharply divided by geographical boundaries. ${ }^{45}$ Thus, the idea of a monopoly on the means of large-scale violence is heavily dependent on a clear distinction between internal and external in the political space.

Studies of state formation have put a strong emphasis on explaining the emergence of the monopoly on the use of force. ${ }^{46}$ A key insight of this strand of research is that modern political rule is based on the organizational capacity to control the 'means of destruction'. 47 State formation research shows that the great challenge of central governments was to organize means of coercion: The state needed to create a standing army, an administrative apparatus, and 'extractive capacities' ${ }^{48}$ Since these elements are all dependent on each other, accumulating power was a very slow and protracted process. Armed competitors needed to be deprived of their organizational capacities one by one, and the state slowly monopolized the means of violence from rivals and local elites. Over centuries, rulers monopolized the means of large-scale violence and succeeded in de-legitimizing the use of force by non-state actors. ${ }^{49}$ After they had acquired monopolies on large-scale violence, states would start policing the population, build rational-legal bureaucracies, and thereby deepen their rule. ${ }^{50}$

However, state formation was not a process that occurred in isolated kingdoms, but in Europe as a region. What emerged were not just a loose collection of states, but a system of states. ${ }^{51}$ The process of statebuilding in each state was driven by the interaction with other (proto-) states, and war has been identified as a major driver of state formation. ${ }^{52}$ The constant threat of conquest set a strong incentive for rulers to strengthen their coercive capabilities. However, the insights of Tilly and other state formation scholars cannot be reduced to the dictum that 'war made the state, and the state made war'. Cooperation has also been central to European state formation. ${ }^{53}$ Statehood developed as a regional institution that regulated who was allowed to participate in regional politics (states) and how interaction should proceed (diplomacy, international law), thereby contributing to the triumph of the state over other forms of political rule. ${ }^{54}$ States mutually recognized their sovereignty, which entailed that each state has a territory in which the government is the final authority and the only actor endowed with the right to wage war. While territorial borders were often contested, they became increasingly fixed over the centuries. When wars were fought over territory, most of them aimed at the distribution of territory, not at the general principle of territorially ordered 
sovereignty. ${ }^{55}$ Smaller exceptions notwithstanding, forceful revision of state borders has become extremely rare in Europe over time.

The rulers of (early) modern Europe developed such norms as sovereignty or the balance of power in a series of treaties, of which the most well-known are the Treaties of Augsburg (1555), Westphalia (1648), Utrecht (1713) and Vienna (1815). ${ }^{56}$ These treaties codified the basic rules according to which the region should be governed and ensured cooperation against actors who sought to abolish the state system in Europe in pursuit of an imperial order. ${ }^{57}$ Overall, the institutionalization of territorial sovereignty in Europe was strong enough to counteract several attempts at empire-building. This stands in stark contrast to the ancient Chinese state formation experience, which ended in the victory of one unit over all others and, eventually, in empire. ${ }^{58}$

To sum up, European state formation was a process that occurred not just within single political entities, but through the systemic interaction between entities that was both competitive (war) and cooperative (institutions).

\section{Outlining the Regional Cooperation Mechanism}

Based on these insights, it becomes evident that a theory that tries to explain success and failure of statebuilding interventions cannot be focused solely on the domestic level or on external actors' strategies. Additionally, the regional political setting needs to be taken into account. ${ }^{59}$ Every border has two sides, and it will only become effective if both sides mutually accept their claim to a monopoly on violence. Current statebuilding practice tries to jumpstart the state by providing the central government with money and expertise, while 'lending' military capabilities. ${ }^{60}$ Thereby, statebuilding interventions have put a strong emphasis on organizational capacities, while mostly ignoring the political dimension of state formation. Establishing the boundaries within which a central government enjoys a monopoly on violence is a political issue that cannot be reduced to organizational capacities, and it cannot be solved at the domestic level. The other states that make up the regional political system need to accept the sovereignty of the state in which intervention takes place. As long as neighboring countries actively or passively support armed groups, statebuilding interventions will not succeed in establishing a monopoly on large-scale violence.

The idea that the ability of armed groups to challenge a government's claim to the monopoly on violence strongly depends on external assistance has already been articulated by Carl Schmitt, ${ }^{61}$ but it has been revived only in recent years. Scholars of civil war have found strong evidence that external assistance is crucial for many non-state armed groups. ${ }^{62}$ However, the advances in civil war research in particular have had surprisingly little impact on studies of statebuilding, even though most interventions deal with (post-) civil war situations. In part, this might be explained by the focus of civil war research on dependent variables that are easier to operationalize than 'statehood', for example the onset of civil war, 
or civil war outcomes in terms of military victory or defeat. With a few notable exceptions, the vast majority of research on statebuilding has so for neglected the importance of regional politics. Haldé ${ }^{63}$ forcefully argues that statebuilding requires the acceptance of sovereignty by powerful neighboring states. Similarly, Zürcher et al. ${ }^{64}$ show that 'bad neighborhoods' reduce the chances of peacebuilding missions to establish democracies in post-conflict societies. While these authors have offered compelling evidence for the importance of regional politics, the causal mechanisms that show how regional politics affect statebuilding outcomes remain unclear.

The argument that I derive from state formation theory is the following: Monopolizing the means of large-scale violence in statebuilding interventions will succeed if key regional actors support the intervention. In this regard, key actors are those who are able to substantially strengthen or weaken armed actors in the state where intervention takes place. These actors include neighboring countries, regional powers and regional organizations. The logic behind this argument is that in typical civil wars, rebels facing weak governments do not necessarily depend on access to transnational spaces because their resistance requires few resources. ${ }^{65} \mathrm{In}$ contrast, the organizational challenges to resist an international statebuilding intervention where external actors deploy a large military contingent are much greater. Only when rebels can count on the (open or tacit) support of neighboring states are they able to keep up their supply networks and shield their leadership from persecution. Where powerful regional states are committed to the creation of sovereign states, they will guard their own borders against rebel groups, and they can use their leverage to force smaller neighboring countries into compliance. This argument does not imply that internal factors do not matter. Rather, the argument is that, given the capacity-building measures at the domestic level typically conducted during statebuilding interventions, it is the regional dimension that makes success more or less likely. Hence, the proposed theory explains why similar domestic circumstances and intervention strategies result in varying outcomes.

The causal mechanism is triggered by the cooperation of key regional states with the intervening actors. Cooperation makes it possible to enforce borders, thereby denying armed groups access to transnational spaces. Without zones of retreat and devoid of access to transnational markets, armed groups will not be able to resist monopolization efforts and will concede to disarmament. The military defeat of rebel groups allows the government to benefit from international technical assistance in building small and professional security forces that are effective, yet politically controllable. The outcome is a state monopoly on violence.

An important insight of this mechanism is that there is a strong interplay between political and organizational aspects. Building reliable security forces in a rather short time frame can only succeed if the intervention can significantly weaken armed groups. Once the political problem of transnational insurgency is solved, the technical aspects of DDR and SSR work rather well. Without this precondition, the constant military pressure will lead to expensive, inflated, and unprofessional security forces. Cases such as Iraq or Afghanistan show how ongoing conflict hampers the establishment of economically sustainable and politically controllable armies. Security forces are inflated and cannot be sustainably funded, 
while the state becomes too militarized for democratic politics. In order to test the proposed mechanism, I will analyze the UN's statebuilding intervention in Sierra Leone through a process-tracing analysis. The case of Sierra Leone is selected because it was a typical statebuilding intervention: A great number of troops were deployed to end a civil war, and liberal statebuilding was conducted through policies such as DDR and SSR. Regarding the outcome, Sierra Leone must be considered a success in terms of monopolization of the means of large-scale violence. During the civil war, a huge variety of armed actors including the rebels (RUF), renegade soldiers (Armed Forces Revolutionary Council), militias (e.g. Civil Defense Forces), mercenaries (e.g. Executive Outcomes) as well as foreign troops (especially from Nigeria and Ghana) fought each other on the territory of a state that controlled only the remnants of an army. However, this market of violence had vanished by 2005, and of these actors only the newly established Armed Forces of Sierra Leone remained while the UN could withdraw its troops.

\begin{tabular}{|c|c|c|c|c|c|}
\hline & \multicolumn{5}{|c|}{ Scope Condition: Liberal Statebuilding Intervention } \\
\hline $\begin{array}{l}\text { Causal } \\
\text { Mechanism }\end{array}$ & Cause & Part 1 & Part 2 & Part 3 & Outcome \\
\hline Theory & $\begin{array}{l}\text { Regional } \\
\text { Cooperation }\end{array}$ & $\begin{array}{l}\text { Enforcement } \\
\text { of Border } \\
\text { Regime }\end{array}$ & $\begin{array}{l}\text { Disarmament } \\
\text { of Non-State } \\
\text { Groups }\end{array}$ & $\begin{array}{l}\text { Building } \\
\text { Sustainable } \\
\text { Armed } \\
\text { Forces }\end{array}$ & $\begin{array}{l}\text { Monopoly on } \\
\text { Violence }\end{array}$ \\
\hline $\begin{array}{l}\text { Empirical } \\
\text { Manifestation }\end{array}$ & $\begin{array}{l}\text { Key regional } \\
\text { actors } \\
\text { support the } \\
\text { statebuilding } \\
\text { intervention }\end{array}$ & $\begin{array}{l}\text { Neighboring } \\
\text { states secure } \\
\text { their borders } \\
\text { against } \\
\text { transnational } \\
\text { rebellion, } \\
\text { either } \\
\text { voluntarily or } \\
\text { through } \\
\text { regional } \\
\text { pressure }\end{array}$ & $\begin{array}{l}\text { Armed } \\
\text { groups are } \\
\text { either } \\
\text { militarily } \\
\text { defeated, or } \\
\text { weakened } \\
\text { enough to } \\
\text { agree to a } \\
\text { DDR process }\end{array}$ & $\begin{array}{l}\text { With external } \\
\text { assistance, } \\
\text { government } \\
\text { builds armed } \\
\text { forces that } \\
\text { are } \\
\text { proportional } \\
\text { in size, } \\
\text { politically } \\
\text { controllable } \\
\text { and } \\
\text { economically } \\
\text { sustainable }\end{array}$ & $\begin{array}{l}\text { International } \\
\text { actors } \\
\text { withdraw. } \\
\text { Government } \\
\text { is the only } \\
\text { actor who } \\
\text { controls the } \\
\text { means of } \\
\text { organized } \\
\text { violence. }\end{array}$ \\
\hline
\end{tabular}

Table 1: Regional Cooperation Mechanism in statebuilding interventions.

\section{Case Study: Statebuilding Intervention in Sierra Leone}

The aim of the international intervention in Sierra Leone was to end the civil war that had ravaged the country since 1991 . Due to a decade of civil war, in which the government and 
Economic Community of West African States Monitoring Group (ECOMOG) troops fought against the Rebel United Front (RUF), Sierra Leone's state infrastructure had unraveled. The UN Mission in Sierra Leone (UNAMSIL) originally was set up as a small mission to oversee the implementation of the Lomé Peace Agreement in 1999. ${ }^{66}$ However, despite wide-ranging concessions in the peace accord, the RUF did not commit itself to disarmament and eventually turned against UN forces in May 2000. ${ }^{67}$ As a reaction, UNAMSIL was transformed into a strong statebuilding intervention. With a mandate to deploy up to 17,500 troops, its goal was '[..] to assist the efforts of the Government of Sierra Leone to extend its authority, restore law and order and stabilize the situation progressively throughout the entire country, and to assist in the promotion of a political process which should lead to a renewed disarmament, demobilization and reintegration program and the holding, in due course, of free and fair elections'. ${ }^{68}$ The outcome of this statebuilding intervention was a state monopoly on largescale violence. In early 2002, President Kabbah officially declared the end of the civil war, and in 2005, the last UN combat troops departed from the country. ${ }^{69}$ The withdrawal of external forces marks the establishment of a monopoly on large-scale violence. ${ }^{70}$ The following sections will test the proposed causal mechanism.

\section{Cause: Regional Cooperation}

The causal mechanism is initiated by cooperative behavior on part of key regional actors. In the case of Sierra Leone, cooperative key actors were the direct neighbor Guinea, armed opposition groups in Liberia, as well as the regional hegemon, Nigeria. As the region's outstanding power, Nigeria's foreign policy has generally a great impact on its wider neighborhood. Since the early 1990s, Nigeria has credibly signaled its commitment to the promotion of sovereignty across Western Africa by participating in UN peacekeeping missions as well as by acting as the driver of regional integration. ${ }^{71}$ In the case of Sierra Leone, Nigeria's cooperation was demonstrated by its provision of over 3,000 troops to UNAMSIL, ${ }^{72}$ and it entailed the facilitation of cooperation through ECOWAS. Overall, ECOWAS members provided about 4,700 of the 17,500 troops deployed by the UN. ${ }^{73}$ Apart from this multilateral support, Guinea also strengthened non-state actors in Liberia that opposed Taylor's regime. ${ }^{74}$ Charles Taylor, both as rebel leader of the NPFL and later (at the time of UNAMSIL) as President of Liberia, pursued an aggressive strategy in the region that challenged the order of the Mano River Basin area. ${ }^{75} \mathrm{He}$ offered the RUF a transnational supply network that made the rebel organization highly resilient. Eventually, ECOWAS' resolve was underlined by its statebuilding intervention in Liberia in August $2003 .^{76}$ Thus, regional cooperation against Taylor first weakened his ability to support the RUF, and eventually transformed Liberia into a cooperative state. In the following sections, the single parts of the mechanism are tested one by one. 


\section{Part 1: Enforcement of Border Regime}

During the civil war in Sierra Leone, the RUF had developed a successful survival strategy. In order to sustain its organizational capacities, it sold diamonds to (and through) Liberia and received supplies and weapons in exchange. Several times, the rebels were severely weakened, for example through the private military company Executive Outcomes in 1995, or an ECOMOG offensive in 1998. Each time, the RUF agreed to ceasefire or peace treaties, but used these periods only to rearm and regroup. Access to transnational space in the region bordering with Liberia made this strategy possible. Thus, great military pressure on the domestic level never led to the disarmament of the RUF, and the rebels could recover each time. $^{77}$

After a major crisis in May 2000 and the increase in its military capacity, UNAMSIL began to switch to 'progressive deployment' across Sierra Leonean territory in mid-2000. While this put increasing military pressure on the RUF, the rebels were still able to control wide areas of the countryside as well as their traditional stronghold close to the Liberian border in the East of the country. The UN forces were backed up by the UK, which however limited its military operation on the Freetown area. Military resistance was fierce, and overall the UN suffered 192 casualties. ${ }^{78}$ Additionally, the UN started to organize economic sanctions against Liberia. Already during the formation stages of UNAMSIL, Nigeria had tried to convince the UN that Taylor's supplies were crucial for the RUF. ${ }^{79}$ In July 2000, the UN put a ban on trade with diamonds from Sierra Leone. More importantly, in March 2001 it also placed an embargo on Liberia, thereby diminishing the ability of the Taylor regime to deal with diamonds sold by the RUF. ${ }^{80}$

Amid UNAMSIL's expansion and display of commitment, the Guinean government intensified its involvement in the conflict. Having tolerated the formation of the Liberians United for Reconciliation and Democracy (LURD) rebel movement on Guinean territory, the Conté administration allowed LURD to start an offensive against the Liberian Taylor regime in July 2000. ${ }^{81}$ Taylor retaliated in September 2000 by coordinating an attack of RUF and Guinean insurgents against the capital, Conakry. ${ }^{82}$ In return, Guinea orchestrated an offensive against the Liberian armed forces and the RUF which involved regular Guinean troops, Sierra Leonean militias and LURD rebels. From late 2000 on, the fighting made diamond smuggling much more difficult for the RUF. ${ }^{83}$ Eventually, LURD conquered the border region in early 2002 and, thereby, cut off the remaining RUF supply network. ${ }^{84}$ Guinea kept up its support for LURD, which increasingly threatened the Taylor regime in Monrovia. However, this episode was only a first step in replacing an actor that had continuously violated the sovereignty of its neighbors. ECOWAS did not simply support Liberian rebels, but it eventually intervened in Liberia in 2003. ${ }^{85}$ The following statebuilding mission has transformed Liberia into a state that respects its neighbors' sovereignty. Hence, the regional alliance strengthened actors who accept the rules of statehood while it weakened those who violated these rules. These gains were further locked in by increased regional integration. Since the late 1990s, and under the influence of the transnational conflicts of the Mano River region, Nigeria has fostered the development of ECOWAS from a project of economic 
integration into a security community. ECOWAS goals today are the mutual support of governments and a commitment to liberal democracy. ${ }^{86}$ As this discussion shows, regional cooperation was not a one-off event, but was sustained and increased over the course of the statebuilding intervention.

To sum up, cooperation between UNAMSIL and regional actors enabled the intervention force to enforce the border regime, and it ended the RUF's access to transnational markets and zones of retreat. The next section shows the impact of this 're-territorialization of the conflict.

\section{Part 2: Disarmament of Non-State Groups}

The resistance against the state's claim on a monopoly on violence depends on organizational capabilities. Neither the Sierra Leonean government and ECOMOG nor UNAMSIL at its early stages were capable of forcing the RUF into compliance. This drastically changed with the de facto closure of the border to Liberia which greatly diminished the organizational capacities of the RUF.

The ceasefire of November 2000 looked similar to the many agreements the RUF had signed before. Despite the strong international troop presence in the country, the RUF held onto the territories in the Kailahun and Kono districts that had been its long-term powerbase. ${ }^{87}$ However, in contrast to prior ceasefires, this time the RUF had to deal with decreasing supplies and, thus could not rebuild its capacities. ${ }^{88}$ During this period, a concerted offensive by Guinean forces and Sierra Leonean militias pushed RUF fighters out of the Western Kambia district, ${ }^{89}$ while the UN and local militias increasingly took control of the Eastern districts. $^{90}$ Deprived of its means to sell diamonds, buy weapons, or hide in a neighbor states' territory, the RUF eventually agreed to disarmament. ${ }^{91}$ In May 2001, the rebel leadership met with representatives of Sierra Leone, the UN and ECOWAS to sign the Abuja Agreement II. ${ }^{92}$

In contrast to all preceding peace treaties signed by the RUF, this time the de facto closure of the border forced the rebels to implement the treaty's provisions. The group immediately began to comply with the DDR program which had been agreed upon in the Lomé Treaty of 1999, but had not been implemented as long as the RUF had access to transnational spaces in the border region. Due to the clear DDR commitment of the RUF, the pro-government militias (Civil Defense Councils, CDF) could be disarmed as well. ${ }^{93}$ Most of this disarmament process occurred in less than a year. 'By January 2002, 72,490 combatants, both RUF and CDF, had been disarmed and a total of 42,000 weapons and 1.2 million rounds of ammunition collected'. ${ }^{94}$ The RUF did not take up arms again after its failed attempts to participate in the formal political system, where the RUF-party garnered only $1.7 \%$ of the vote. ${ }^{95}$ Hence, by 2002, Sierra Leone had been freed of armed groups capable of challenging the government. 


\section{Part 3: Building sustainable Armed Forces}

In order to sustain the monopoly on violence, the government needs armed forces that are economically sustainable and politically controllable. The end of the armed challenge to the government greatly improved the prospects for building armed forces according to SSR principles.

The SSR program in Sierra Leone is rather typical for a statebuilding mission. Initial efforts at SSR preceded the full-scale intervention, as the UK started a program in late 1999 with the goal to completely rebuild the Republic of Sierra Leonean Armed Forces (RSLAF). ${ }^{96}$ However, this first phase failed to build a professional force of appropriate size. As in other interventions where conflict is ongoing, the army-building efforts resulted in a quick assembly of a large, poorly trained force of about 12,000 soldiers. ${ }^{97}$ The subsequent reintegration program for ex-rebels and former militiamen further inflated the size of the army to 14,500 men. This tendency, that can be observed in cases like Afghanistan or Iraq as well, produced a RSLAF that was oversized, staffed with unreliable personnel and marked by little professionalism. $^{98}$

However, the defeat of the RUF and the disarmament of the CDF militias created an environment in which SSR could eventually meet many of its aspirations. Led by the UK, the SSR program drastically reduced the size of the RSLAF. By 2010, the armed forces had shrunk by $40 \%$ to 8,500 troops. ${ }^{99}$ The reduced size had two important effects: On the one hand, the recruitment benchmarks could be increased and, thereby, qualified personnel could be recruited. More meritocratic recruitment allowed for an ethnically and regionally balanced personnel structure, which in turn increased political control over the armed forces. ${ }^{100}$ Complemented by a reform of the Ministry of Defense which guaranteed a civilian oversight over the army, ${ }^{101}$ and a streamlining of the military leadership, this contributed to an overall increase in professionalism in the armed forces. On the other hand, less personnel means reduced costs. This is crucial for a poor country like Sierra Leone, as it affects the sustainability of state rule. Since the end of the war, both government spending on defense as well as the dependence on foreign aid have dropped significantly. ${ }^{102}$ As the data indicates, while still being dependent on foreign donors, Sierra Leone has successively moved towards a sustainable monopoly on violence. 


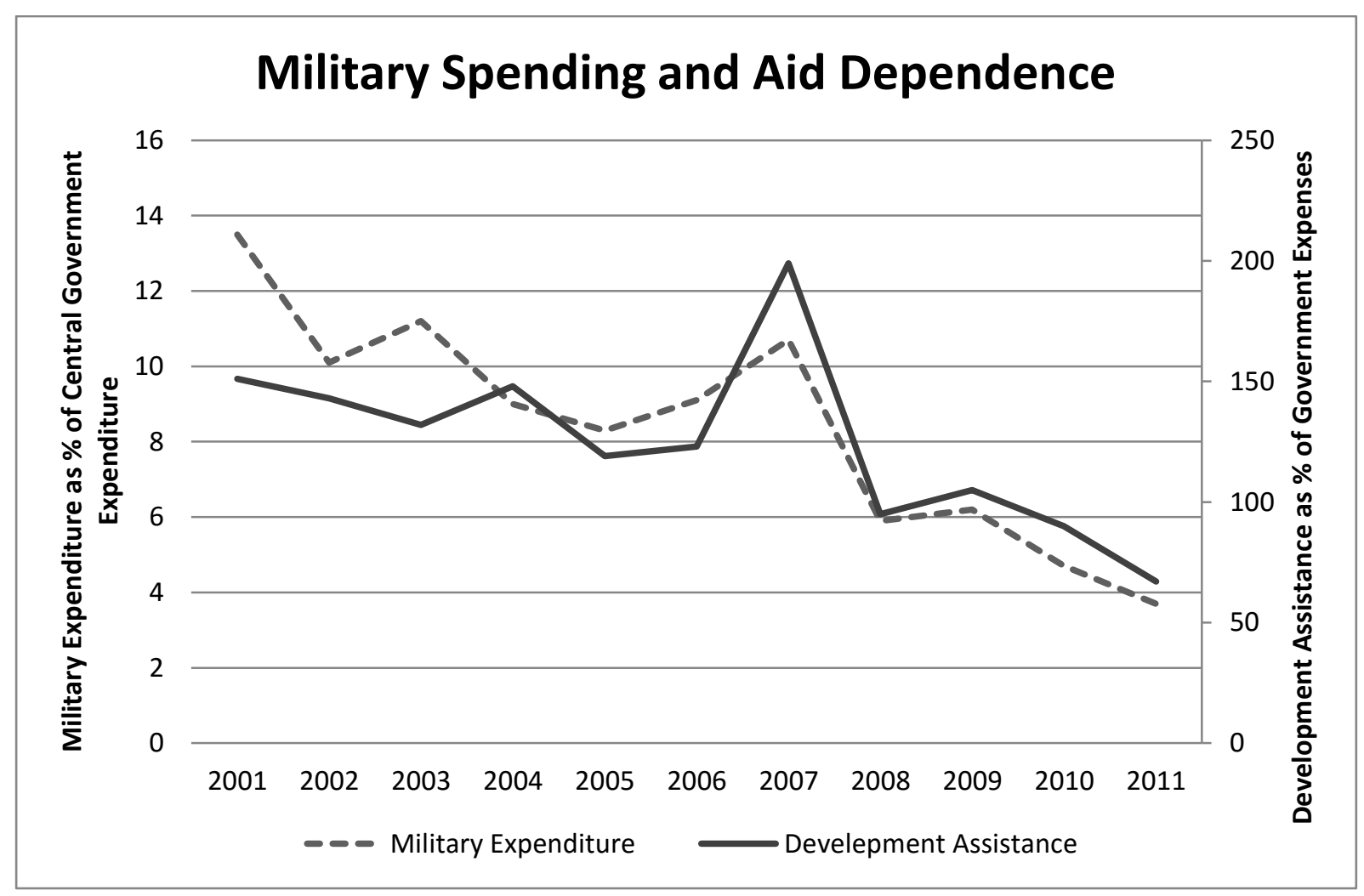

Figure 1: Military expenditures and Official Development Assistance (ODA). ${ }^{103}$

\section{Outcome}

In 2005, UN troops completed their withdrawal from Sierra Leone. Thus, without armed nonstate groups or international forces on its territory, the Sierra Leonean government is the only actor that controls the means of large-scale violence. The RSLAF have been downsized while at the same their professionalism has been increased. The public perception of the armed forces has markedly improved. The fact that the RSLAF have not interfered with elections and the change of government in 2007 underlines the high degree of institutionalization of the monopoly on violence. As a result, Sierra Leone has turned into an electoral democracy in which the All People Congress (APC) and Sierra Leone Peoples Party (SLPP) compete for votes in free and fair elections. ${ }^{104}$ Compared to both other interventions as well as to the situation prior to the intervention, statebuilding in Sierra Leone can be seen as successful.

However, the monopoly on large-scale violence is only one necessary condition for liberal statehood. Despite its control over the means of destruction, the state of Sierra Leone also points to the limitation of liberal statebuilding. Democracy is not fully consolidated, as violent escalations during election times and efforts to politicize the police force indicate. ${ }^{105}$ The continued strength of chiefdoms has sustained a system of legal pluralism, and smallscale violence regulation remains partly in the hands of chiefs. ${ }^{106}$ Not only does this system regulate land rights in ways that some have identified as causes of the civil war, ${ }^{107}$ but it is effectively preventing the establishment of a liberal rule of law. ${ }^{108}$ Nevertheless, all of these 
observations underline that it useful to analyze single aspects of statehood in order to make more fine-grained judgments about success or failure of statebuilding interventions.

\section{Conclusion}

In many regards, Sierra Leone could be seen as a worst case scenario by conventional standards: At the time of intervention, the country was poor, it lacked infrastructure, it was subject to a decade of civil war and it never had a strong state. Worse still, the interveners were a rather incoherent force of mostly ill-equipped troops. Nevertheless, the scope and speed of UNAMSIL's success is striking. Once the UN intervened decisively, the RUF gave in and could be disarmed alongside thousands of CDF fighters. The RUF transformed into a political party and was defeated at the ballot box. Within only a few years, the army was rebuilt as a smaller but much more professional and economically more sustainable force. All these achievements are extremely surprising given the longevity displayed by the RUF during the 1990s. As this article argued, the condition that let UNAMSIL succeed was the cooperative behavior of key regional states.

This paper aimed to explain the success of statebuilding interventions in terms of the monopoly on large-scale violence. Hence, the scope is very limited and the results are not meant to contradict large parts of the literature that focus on a variety of issues, from the liberalizing aspects of interventions to their economic consequences. Instead, it proposed a regional theory of statebuilding that can explain why interventions succeed in creating a monopoly on large-scale violence, the basic condition of modern statehood. It built on existing work and combined it with insights from state formation theory in order to build a theoretical framework applicable to current interventions, and it tested the proposed theory on a case through employing process-tracing. The evidence strongly suggests that the expected causal mechanism was present in the case of Sierra Leone. Nevertheless, further (comparative) research is necessary to test and strengthen the theory. The case had a comparatively favorable regional setting because the country has less than one thousand kilometers of land boundaries, it is surrounded by only two direct neighbors of whom one supported the Sierra Leonean government, and there is an undisputed regional hegemon. Guinea, Liberia, and Sierra Leone have established monopolies on large-scale violence ${ }^{109}$ and they cooperate within their sub-regional organization (Mano River Union) to develop common security approaches, ${ }^{110}$ thereby reinforcing the stability of their border regions. Even where governments share a commitment to the norm of sovereignty, a greater number of neighboring states or great powers is likely to make any monopolization effort more complicated.

Despite these reservations, a brief comparison across cases lends support to the argument that regional cooperation and regional competition affects the ability of statebuilding interventions to establish monopolies on violence. The list of failures is long: In Afghanistan, the Taliban receive strong support from Pakistan and are thus able to resist monopolization efforts. In Iraq, militias on all sides have supporters in neighboring states such as Iran or Saudi-Arabia, thereby leading to a fragmentation of the means of violence. In the 
Democratic Republic of Congo, Rwandan support ensured that armed confrontations endured despite a massive UN presence. Ethnic groups in the Balkans have enjoyed support from their 'motherlands' in the cases of both Bosnia and Kosovo. In contrast, where key regional actors have cooperated, interventions have created basic monopolies on violence. In Western Africa, where Nigeria and the regional organization ECOWAS have supported intervention, governments in both Liberia and Sierra Leone do not face armed competitors. In East Timor, agreement among Australia and Indonesia served as a background for successful intervention.

The results presented in this article lead to three broader conclusions: First, if regional cooperation is available, some of the 'technical' fixes such as DDR and SSR work to a certain extent. UNAMSIL was far more successful in terms of ending a conflict, building a state and fostering democracy than one would expect based on critical theories. Second, regional politics are not static. Depending on the regional constellation, there might be some leeway for intervening actors to facilitate cooperation among regional actors. Yet, in an increasingly multipolar world, the ability of Western states to accommodate great powers or to transform whole regions might be rapidly declining. Third, different elements of statehood differ in terms of their complexity and the time they need to develop. As the example of Sierra Leone shows, a monopoly on large-scale violence can be achieved within the short time span of an intervention. However, even in such a successful case, developing a functioning state bureaucracy or cultivating the rule of law could take much longer than any external actor would be willing to sustain a costly statebuilding mission. 


\section{NOTES}

${ }^{1}$ Kabia, Humanitarian intervention and conflict resolution in West Africa : from ECOMOG to ECOMIL, Farnham, England ; Burlington, VT: Ashgate Pub. Company, 2009, pp. 104-109; Keen, Conflict and Collusion in Sierra Leone, Oxford, UK: James Currey Publishers, 2005, pp. 25-35

${ }^{2}$ Olonisakin, Peacekeeping in Sierra Leone : the story of UNAMSIL, Boulder: Lynne Rienner Publishers, 2008; Keen, 2005, pp. 260-26; Gberie, A dirty war in West Africa : the RUF and the destruction of Sierra Leone, London: Hurst \& Company, 2005, pp. 162-169

${ }^{3}$ Beach and Pedersen, Process-tracing methods : foundations and guidelines, Ann Arbor: University of Michigan Press, 2013,

${ }^{4}$ Tansey, 'Evaluating the Legacies of State-Building: Success, Failure, and the Role of Responsibility', International Studies Quarterly 58, 1, 2013: pp. 2-3

${ }^{5}$ Goertz and Mahoney, A tale of two cultures : qualitative and quantitative research in the social sciences, Princeton, N.J.: Princeton University Press, 2012, pp. 9-12

${ }^{6}$ King, et al., Designing social inquiry, Princeton, NJ: Princeton Univ. Press, 1994, pp. 208212

${ }^{7}$ Gerring, 'The Mechanismic Worldview: Thinking Inside the Box', British Journal of Political Science 38, 01, 2008: p. 4

${ }^{8}$ Wulf, 'Reconstructing the Public Monopoly of Legitimate Force', In: Private Actors and Security Governance, ed. Bryden and Caparini Berlin/Zürich: Lit, 2006; Jachtenfuchs, et al., Policing Among Nations. Internationalizing the Monopoly Force, 28 2008,

${ }^{9}$ Weber, Wirtschaft und Gesellschaft, Tübingen: J.C.B. Mohr, 1972, p. 82; Pierson, The modern state, London ; New York: Routledge, 2011, pp. 7-; Spruyt, The Sovereign State and its Competitors, Princeton, New Jersey: Princeton University Press, 1994, p. ; Migdal and Schlichte, 'Rethinking the State', In: The Dynamics of States, ed. Schlichte Hampshire, UK. Burlington, VT.: Ashgate Publishing Limited, 2005, p. 15

${ }^{10}$ Wesley, 'The State of the Art on the Art of State Building', Global Governance: A Review of Multilateralism and International Organizations 14, 3, 2008: pp. 376-379

${ }^{11}$ Bliesemann de Guevara, Statebuilding and state-formation : the political sociology of intervention, Milton Park, Abingdon, Oxon ; New York: Routledge, 2012, p. ; Paris and Sisk 2009: The dilemmas of statebuilding. London: Routledge, p. 1; Mac Ginty, 'Warlords and the liberal peace: state-building in Afghanistan', Conflict, Security \& Development 10, 4, 2010: pp. 580-58; Lake, 'Building Legitimate States after Civil Wars', In: Strengthening Peace in Post-Civil War States, ed. Hoddie and Hartzell Chicago: University of Chicago Press, 2010, p. 31

${ }^{12}$ Weber, 1972, p. 824

13 '[..] daß der moderne Staat ein anstaltsmäßiger Herrschaftsverband ist, der innerhalb eines Gebietes die legitime physische Gewaltsamkeit als Mittel der Herrschaft zu monopolisieren mit Erfolg getrachtet hat [... '

${ }^{14} \mathrm{cf}$. Migdal and Schlichte, 2005,

15 'War Making and State Making as Organized Crime', In: Bringing the State Back In, ed. Evans, et al. Cambridge, UK: Cambridge University Press, 1985,

${ }^{16}$ Tilly, 'War Making and State Making as Organized Crime', In: Bringing the State Back In, ed. Evans, et al. Cambridge, UK: Cambridge University Press, 1985, pp. 173-175

${ }^{17}$ The art of coercion : the primitive accumulation and management of coercive power, $\mathrm{New}$ York: Columbia University Press, 2011, pp. 7-8

${ }^{18}$ Olson, 'Dictatorship, Democracy, and Development', The American Political Science Review 87, 3, 1993: pp. 568-569 
${ }^{19}$ Trotha, 'Die Zukunft liegt in Afrika. Vom Zerfall des Staates, von der Vorherrschaft der konzentrischen Ordnung und vom Aufstieg der Parastaatlichkeit', Leviathan 28, 2, 2000: p. 26; Lake, 2010, pp. 38-43.

${ }^{20}$ Weber, 1972, pp. 122-124

${ }^{21}$ Møller and Skaaning, 'Stateness first?', Democratization 18, 1, 2011: pp. 16-17

${ }^{22}$ Bliesemann de Guevara, 2012, pp. 2-4

${ }^{23}$ Paris and Sisk, 2009, pp. 13-1; Lake, 'The Practice and Theory of US Statebuilding', Journal of Intervention and Statebuilding 4, 3, 2010: p. 259

${ }^{24}$ Dobbins, The beginner's guide to nation-building, Santa Monica, Calif.: Rand, 2007, pp. 19-22

${ }^{25}$ Lake, 2010, pp. 272-273

${ }^{26}$ Rubin, 'The Politics of Security in Postconflict Statebuilding ', In: Building States to Build Peace, ed. Call and Wyeth Boulder, Colorado: Lynne Rienner Publishers, 2008, pp. 28-31

${ }^{27}$ Chesterman, You, The People: The United Nations, Transitional Administration, and StateBuilding, Oxford, UK: Oxford University Press, 2004, pp. 99-101

${ }^{28}$ Caplan, Exit strategies and state building, Oxford and New York: Oxford University Press, 2012, pp. 311-313

${ }^{29}$ Bliesemann de Guevara, Staatlichkeit in Zeiten des Statebuilding : Intervention und Herrschaft in Bosnien und Herzegowina Frankfurt am Main ;: New York : P. Lang,, 2009, pp. 78-87

${ }^{30}$ e.g. Mac Ginty, 'Hybrid Peace: The Interaction Between Top-Down and Bottom-Up Peace', Security Dialogue 41, 4, 2010; Chandler, 'The state-building dilemma: good governance or democratic governance', In: State-building.Theory and practice, ed. Hehir London:

Routledge, 2007; Richmond, The transformation of peace, Basingstoke England ; New York: Palgrave Macmillan, 2005,

${ }^{31}$ Mac Ginty, 'Hybrid Peace: The Interaction Between Top-Down and Bottom-Up Peace', 2010, pp. 391-392

32 Jackson, 'Security Sector Reform and State Building', Third World Quarterly 32, 10, 2011 : pp. 1812-1813

${ }^{33}$ Jackson, 'Security Sector Reform and State Building', Third World Quarterly 32, 10, 2011 : p. 1810 .

${ }^{34}$ Pugh, et al., War Economies in a Regional Context: Challenges of Transformation, Boulder, Colorado: Lynne Rienner Publishers, 2003,

${ }^{35}$ Cooper, et al., 'The end of history and the last liberal peacebuilder: a reply to Roland Paris', Review of International Studies 37, 04, 2011: p. 2000

${ }^{36}$ Giustozzi, 2011,

${ }^{37}$ Giustozzi, 2011, pp. 175-180

38 'The peacebuilder's contract: How external statebuilding reinforces weak statehood', In: The dilemmas of statebuilding. Confronting the contradictions of postwar peace operations, ed.

Paris and Sisk London: Routledge, 2009,

${ }^{39}$ Zürcher, et al., Costly Democracy. Peacebuilding and Democratization After War, Stanford, Cal.: Stanford University Press, 2013, pp. 4-5

${ }^{40}$ Herbst, States and power in Africa : comparative lessons in authority and control, Princeton, N.J.: Princeton University Press, 2000; Thies, 'State Building, Interstate and Intrastate Rivalry: A Study of Post-Colonial Developing Country Extractive Efforts, 19752000', International Studies Quarterly 48, 1, 2004; Centeno, Blood and debt : war and the nation-state in Latin America, University Park, Pa.: Pennsylvania State University Press, 2002; Ahram, Proxy Warriors. The Rise and Fall of State-Sponsored Militias, Stanford, California: Stanford University Press, 2011; Slater, Ordering power : contentious politics and 
authoritarian leviathans in Southeast Asia, Cambridge ; New York: Cambridge University Press, 2010,

${ }^{41}$ Richmond, 'Failed statebuilding versus peace formation', Cooperation and Conflict 48, 3, 2013; Bliesemann de Guevara, Statebuilding and state-formation : the political sociology of intervention, 2012,

42 e.g. Herbst, 2000; Haldén, 'Systems-building before state-building: on the systemic preconditions of state-building', Conflict, Security \& Development 10, 4, 2010:

${ }^{43}$ Spruyt, 1994, p. 34

${ }^{44}$ Ruggie, 'Territoriality and beyond: problematizing modernity in international relations', International Organization 47, 01, 1993: p. 151

${ }^{45}$ Giddens, The Nation-State and Violence, Berkeley and Los Angeles: University of California Press, 1985, pp. 49-52

${ }^{46}$ Elias, The civilizing process : sociogenetic and psychogenetic investigations, Oxford ; Malden, Mass.: Blackwell Publishers, 1939[2000]; Tilly, Coercion, capital, and European states, AD 990-1992, Cambridge, MA: Blackwell, 1992,

${ }^{47}$ Malešević, The Sociology of War and Violence, Cambridge, UK: Cambridge University Press, 2010, p. 78

${ }^{48}$ Tilly, Coercion, capital, and European states, AD 990-1992, 1992, p. Ch 3

49 Tilly, 'War Making and State Making as Organized Crime', 1985, pp. 172-175

${ }^{50}$ Tilly, Coercion, capital, and European states, AD 990-1992, 1992, pp. 74-76

${ }^{51}$ Bull, The Anarchical Society. A Study of Order in World Politics, New York, NY; Chichester, West Sussex: Columbia University Press, 2002, pp. 38-49

${ }^{52}$ Tilly, Coercion, capital, and European states, AD 990-1992, 1992,

${ }^{53}$ Thomson, 'State Sovereignty in International Relations: Bridging the Gap between Theory and Empirical Research', International Studies Quarterly 39, 2, 1995: pp. 221-222

${ }^{54}$ Spruyt, 1994, pp. 6-7

${ }^{55}$ Ruggie, 1993, pp. 162-163

${ }^{56}$ Haldén, 'Against Endogeneity: The systemic preconditions of state formation', In: New Agendas in Statebuilding: Hybridity, contingency and history, ed. Egnell and Haldén New York: Routledge, 2013,

${ }^{57}$ Ruggie, 1993, p. 146

${ }^{58}$ Hui, War and state formation in ancient China and early modern Europe, New York NY: Cambridge University Press, 2005,

${ }^{59}$ Haldén, 'Systems-building before state-building: on the systemic preconditions of statebuilding', 2010, pp. 42-43

${ }^{60}$ Rubin, 2008, p. 28

${ }^{61}$ Schmitt, The Theory of the Partisan: A Commentary/Remark on the Concept of the Political, East Lansing, MI: Michigan State University Press, 1963[2004], pp. 52-54

${ }^{62}$ Gleditsch, 'Transnational Dimensions of Civil War', Journal of Peace Research 44, 3, 2007 : p. 9; Pugh, et al., 2003; Lyall and Wilson, 'Rage Against the Machines: Explaining Outcomes in Counterinsurgency Wars', International Organization 63, 01, 2009:

63 'Against Endogeneity: The systemic preconditions of state formation', 2013, pp. 43-45

${ }^{64}$ 2013, pp. 9-10

${ }^{65}$ Kalyvas and Balcells, 'International System and Technologies of Rebellion: How the End of the Cold War Shaped Internal Conflict', American Political Science Review 104, 03, 2010: pp. 421-423

${ }^{66}$ UNSC, Peace Agreement between the Government of Sierra Leone and the Revolutionary United Front of Sierra Leone 1999, p. 20

${ }^{67}$ Olonisakin, 2008, p. 5; Kabia, 2009, p. 127 
${ }^{68}$ UNSC, Ninth Report of the Secretary-General on the United Nations Mission in. Sierra Leone. Document no. S/2001/228., 2001, p. §58

${ }^{69}$ Bah, 'Sierra Leone', In: Exit Strategies and International State Building, ed. Caplan Oxford, UK: Oxford University Press, 2012, pp. 110-112

${ }^{70}$ BTI, Country Report - Sierra Leone, 2014,

${ }^{71}$ Kabia, 2009, pp. 57-6; Rashid, 'The Sierra Leone Civil War and the Remaking of ECOWAS', Research in Sierra Leone Studies (RISLS) 1, 2013: pp. 6-; Aning and Salihu, 'Regional approaches to statebuilding II: The African Union and ECOWAS', In: Political Economy of Statebuilding, ed. Berdal and Zaum London, UK: Routledge, 2013,

${ }^{72}$ UNSC, Fourth Report of the Secretary-General on the United Nations Mission in. Sierra Leone. Document no. S/2000/455., 2000, p. 18

${ }^{73}$ Ibid.

${ }^{74}$ ICG, Liberia: The Key to Ending Regional Instability, N 43 2002, p. 4

${ }^{75}$ Gerdes, Civil War and State Formation. The Political Economy of War and Peace in Liberia, Frankfurt-on-Main, Germany: Campus Verlag, 2013, pp. 161-165

${ }^{76}$ Gerdes, Civil War and State Formation. The Political Economy of War and Peace in Liberia, Frankfurt-on-Main, Germany: Campus Verlag, 2013, pp. 167-168

${ }^{77}$ Hazen, What rebels want : resources and supply networks in wartime, Ithaca: Cornell University Press, 2013, pp. 73-75

${ }^{78}$ UN, Sierra Leone - UNAMSIL - Facts and Figures 2005. Online. Available at http://www.un.org/en/peacekeeping/missions/past/unamsil/facts.html. 03.04. 2014.

${ }^{79}$ Olonisakin, 2008, p. 38

${ }^{80}$ UNSC, Report of the Panel of Experts pursuant to Security Council resolution 1343 (2001), paragraph 19, concerning Liberia. Document no. S/2001/1015, 2001, p. 76

${ }^{81}$ ICG, $\mathrm{N}^{\circ} 432002$, p. 4.

${ }^{82}$ ICG, N43 2002, pp. 4-5

${ }^{83}$ Hazen, 2013, pp. 99-101

${ }^{84}$ Hazen, 2013, p. 130

${ }^{85}$ Gerdes, 2013, pp. 167-168

${ }^{86}$ Rashid, 2013, pp. 6-7

${ }^{87}$ Olonisakin, 2008, pp. 101-102

${ }^{88}$ Hazen, 2013, p. 82

${ }^{89}$ Gberie, 2005, pp. 172-17; ICG, $\mathrm{N}^{\circ} 43$ 2002, pp. 4-5

${ }^{90}$ UNSC, Ninth Report of the Secretary-General on the United Nations Mission in. Sierra Leone. Document no. S/2001/228., 2001, pp. 4-5

${ }^{91}$ Keen, 2005, pp. 267-268

${ }^{92}$ Olonisakin, 2008, pp. 103-104

${ }^{93}$ UNSC, Tenth Report of the Secretary-General on the United Nations Mission in. Sierra Leone. Document no. S/2001/627, 2001, p. 3

${ }^{94}$ Gberie, 2005, p. 171

${ }^{95}$ ICG, $\mathrm{N}^{\circ} 432002$, p. 1

${ }^{96}$ Albrecht and Jackson, Security System Transformation in Sierra Leone, 1997-2007, 2009, pp. 22-23

${ }_{97}$ Albrecht and Jackson, Security System Transformation in Sierra Leone, 1997-2007, 2009, pp. 23-2; Nilsson and Kovacs, 'Different Paths of Reconstruction: Military Reform in PostWar Sierra Leone and Liberia', International Peacekeeping 20, 1, 2013: p. 7

${ }^{98}$ Nilsson and Kovacs, 2013, p. 7

${ }^{99}$ Nilsson and Kovacs, 2013, pp. 10-11

${ }^{100}$ Nilsson and Kovacs, 2013, p. 12

${ }^{101}$ Gbla, 'Security sector reform under international tutelage in Sierra Leone', ibid.13, 2006: p. 84 
${ }^{102}$ WorldBank, World Bank Open Data 2014. Online. Available at http://data.worldbank.org/. 02.04. 2014.

${ }^{103}$ Ibid; ibid..

${ }^{104}$ BTI, 2014, pp. 7-8

${ }^{105}$ Downie, Building Police Institutions in Fragile States. Case Studies from Africa, 2013, p. 10

${ }^{106}$ Baker, Multi-choice policing in Africa, Uppsala: Nordiska Afrikainstitutet, 2008, pp. 144145

${ }^{107}$ Peters and Richards, 'Rebellion and Agrarian Tensions in Sierra Leone', Journal of Agrarian Change 11, 3, 2011: pp. 382-385

${ }^{108}$ Denney, 'Liberal Chiefs or Illiberal Development? The Challenge of Engaging Chiefs in DFID's Security Sector Reform Programme in Sierra Leone', Development Policy Review 31, 1, 2013: pp. 13-14

${ }^{109}$ BTI, Bertelsmann Transformation Index 2014 - Dataset, 2014, The data set provides a measure for the monopoly on violence, assigning countries values from 1 (no monopoly) to 10 (fully monopoly). Guinea, Liberia and Sierra Leone each have a score of 8, indicating that a monopoly on violence has been established in principle.

${ }^{110}$ UNOWA, Vers une stratégie de sécurité pour l'Union du Fleuve Mano. Towards a Security Strategy for the Mano River Union 2013. Online. Available at http://unowa.unmissions.org/Portals/UNOWA/Press\%20release/130629\%20Press\%20release \%20MRU_FR_ENGL.pdf. 15.10.2014. 